\title{
Use of GC/MS to identify chemical constituents and cytotoxic activity of the leaves of Phoradendron mucronatum and Phoradendron microphyllum (Viscaceae)
}

\author{
ISLA V.G.A. BASTOS ${ }^{1}$, TATIANE B. DE OLIVEIRA ${ }^{1}$, MARIA D. RODRIGUES ${ }^{1}$, GARDÊNIA C.G. MILITÃ ${ }^{2}$, \\ TERESINHA G. DA SILVA ${ }^{1}$, IZABEL C.C. TURATTI ${ }^{3}$, NORBERTO P. LOPES ${ }^{3}$ and SEBASTIÃO J. DE MELO \\ ${ }^{1}$ Universidade Federal de Pernambuco, Centro de Biociências, Departamento de Antibióticos, \\ Av. Prof. Artur de Sá, s/n, Cidade Universitária, 50740-520 Recife, PE, Brazil \\ ${ }^{2}$ Universidade Federal de Pernambuco, Centro de Biociências, Departamento de Fisiologia e \\ Farmacologia, Rua Nelson Chaves, s/n, Cidade Universitária, 50670-901 Recife, PE, Brazil \\ ${ }^{3}$ Universidade de São Paulo, Faculdade de Ciências Farmacêuticas de Ribeirão Preto, Departamento \\ de Física e Química, Av. do Café, s/n, Monte Alegre, 14040-903 Ribeirão Preto, SP, Brazil \\ Manuscript received on September 1, 2016; accepted for publication on November 18, 2016
}

\begin{abstract}
Phoradendron mucronatum and P. microphyllum are plants that found in tropical and subtropical areas, used in traditional medicine and popularly known as mistle-thrush. The aim of this study was to identify the chemical constituents of different leaf extracts from P. mucronatum and P. microphyllum and assess cytotoxic activity against strains from a human tumour cells. Extracts obtained with hexane, dichloromethane, chloroform and ethyl acetate from the leaves were analysed by gas chromatography coupled with mass spectrometry (GC-MS) and the cytotoxicity was assessed by the MTT method (bromide (3-(4,5-dimethylthiazol-2-yl)-2,5-diphenyltetrazolium bromide)). The tested human tumour cells were NCI-H292 (human pulmonar mucoepidermoid carcinoma), MCF-7 (human breast adenocarcinoma) and HEp-2 (epidermoid carcinoma of the larynx). Analysis by GC/MS of the extracts from leaves of P. microphyllum and P. mucronatum detected 51 different compounds, such as alkaloids, diterpenes, triterpenes, sterols, alcohols, aldehydes, fatty acids and hydrocarbons. In the cytotoxic evaluation, hexane and ethyl acetate extracts from the leaves P. microphyllum inhibited cell growth of NCI-H292 strains (72.97\%) and HEp-2 (87.53\%), respectively. The extracts of $P$. mucronatum species showed an inhibitory effect towards NCI-H292 (83.19\%/hexane), MCF-7 (88.69\%/dichloromethane) and HEp-2 (93.40\%/ hexane). The extracts showed cytotoxic activity against the tested strains, especially the P. mucronatum, which presented the highest percentages of inhibition of cell growth.
\end{abstract}

Key words: Cytotoxicity, Gas Chromatography, Phoradendron microphyllum, Phoradendron mucronatum.

\section{INTRODUCTION}

Most current drugs are derived, directly or indirectly from the chemical constituents of higher plants.

Correspondence to: Sebastião José de Melo

E-mail: melosebastiao@yahoo.com.br
About $60 \%$ of the drugs used for the treatment of cancer have been isolated from vegetable products (Gordaliza 2007).

The main plant-derived compounds with anticancer properties are alkaloids and terpenoids (Gupta et al. 2005). Examples are derivatives of 
etoposide and teniposide lignans (Allen et al. 2003, Choi et al. 2008), vincristine and vinblastine from Catharanthus roseus (L.) G. Don (Johnson et al. 1963, Carvalhaes et al. 2002), semi-synthetic derivatives of podophyllotoxin isolated from species of the genus Podophyllum (Berberidaceae) (Jacobo-Herrera et al. 2016), taxol, and docetaxel from Taxus brevifolia Nutt. (Wani et al. 1971) and semi-synthetic derivatives from camptothecin, irinotecan and topotecan isolated from Camptotheca acuminata (Nyssaceae) (Cragg et al. 1993, 1994, Wang 1998).

The analysis of anticancer activity is based on assays that use established cell lines where the toxic effect of plant extracts can be measured. Cytotoxic screening models provide important preliminary data for selecting plant extracts or compounds with antineoplasic properties (Alonso-Castro et al. 2011).

Phoradendron is a genus of the Viscaceae family with approximately 234 species. Mistletoes are plants that occur in tropical and subtropical areas of both hemispheres (Cronquist 1981). Several species have wide use in traditional medicine. For example, P. carneum Urb., P. galeottii Trel., P. reichenbachianum (Seem.) Oliver and $P$. serotinum (Raf.) M.C. Johnst are used to treat dermatological disorders and skin tumors (Alonso-Castro et al. 2011).

Phoratoxinas isolated from $P$. tomentosum manifests cytotoxic activity in different cell lines (Johansson et al. 2003). The methanol extract of the leaves of $P$. vernicosum Greenm. presented activity against nasopharyngeal carcinoma (CaamalFuentes et al. 2011). The aqueous extract the leaves of $P$. serotinum (Raf.) MC Johnst. caused toxic effects against breast carcinoma (Jacobo-Salcedo et al. 2011) and ethanol extract shows cytotoxic activity against lung epithelial cells (Alonso-Castro et al. 2012).

The Phordendron microphyllum (Pohl ex DC.) Trel and Phordendron mucronatum (DC.) Krug \&
Urb species are popularly known as "herbal" or "bird dung" and can be found as parasite species in the northeastern semiarid region of Brazil (Ferreira et al. 2007).

Scientific reports concerning this species are scarce. The present study then was mounted to identify the chemical constituents of hexane, dichlomethane, chloroform and ethyl acetate extracts from the leaves of $P$. mucronatum and P. microphyllum and to evaluate their cytotoxic activity against human tumour cell lines.

\section{MATERIALS AND METHODS}

PLANT MATERIAL

The species $P$. mucronatum was collected in the municipality of Buique - Pernambuco, (08 $37^{\circ} 23^{\prime \prime}$ S 3709'21" W). P. microphyllum (Pohl ex DC.) Trel (Viscaceae) was collected at Fazenda Canto dos Passaros in Sao Jose do Espinharas, Paraiba, (06 52'56" S 37¹7'12” W). Samples of $P$. mucronatum and $P$. microphyllum were identified by curators Rita Pereira and Olivia Cano, respectively, and deposited in the Dárdano of the Andrade Lima Herbarium of the Agricultural Institute of Pernambuco (IPA) under registration numbers 63330 and 87746 , respectively.

\section{PREPARATION OF THE EXTRACT}

A dry power of the $P$. microphyllum and $P$. mucronatum (30 g) leaves was extracted at room temperature for 30 minutes three times consecutively by maceration in an ultrasonic bath (Uniqu USC - 1400) using solvents with different polarities: hexane (Hx), dichloromethane (DCM), chloroform (CF) and ethyl acetate (EtOAc). Then it was filtered and the crude extracts were obtained after evaporation of the solvents under reduced pressure at $40{ }^{\circ} \mathrm{C}$. Ten $\mathrm{mg}$ of the extracts was dissolved in $2 \mathrm{ml}$ of ethyl acetate for analysis by Gas Chromatography coupled to Mass Spectrometry (GC/MS). 


\section{GC-MS ANALYSIS}

Analysis of compounds from extracts of $P$. microphyllum and P. mucronatum was performed at the Research Center of Natural and Synthetic Products, University of São Paulo (USP-Ribeirão Preto), using GC/MS, Shimadzu, model QP 2010. Separation of the chemical constituents was carried out using a DB-5MS column [(5\%-Phenyl)methylpolysiloxane] brand Agilent J\&W GC Columns, $30 \mathrm{~m}$ long, $0.25 \mathrm{~mm}$ internal diameter, thickness of the film $0.25 \mu \mathrm{m}$. The carrier gas was helium. The operating conditions of the gas chromatograph were: column internal pressure of $97.4 \mathrm{kPa}$, column flow of gas at $1.3 \mathrm{ml} \mathrm{min}^{-1}$ column, injector temperature $260{ }^{\circ} \mathrm{C}$, detector temperature at the interface (GC/MS) of $290{ }^{\circ} \mathrm{C}$. The initial column temperature was $100{ }^{\circ} \mathrm{C}$ for 4 min, followed by an increase of $3{ }^{\circ} \mathrm{C} \mathrm{min}^{-1}$ up to $300{ }^{\circ} \mathrm{C}$ and kept constant for $90 \mathrm{~min}$. The split ratio was $5: 1$. The mass spectrometer was programmed to perform readings in a range of 50 to $500 \mathrm{Da}$ at intervals of $0.30 \mathrm{~s}$, with ionization energy of $70 \mathrm{eV}$. One $\mu l$ of the different extracts was injected $(10 \mathrm{mg}$ dissolved in $2 \mathrm{ml}$ ethyl acetate). A mixture of linear hydrocarbons (C9-C20, C21-C40) was injected under the same conditions in order to identify the chemical constituents. The identification of the constituents was performed by analyzing and comparing the mass spectra based on data libraries (FFNSC1.3.lib, WILEY7.LIB, NIST08s.LIB, MY LIBRARY.lib) using a GC/MS instrument, whose índices showed a similarity of greater than or equal to $90 \%$. Relative quantification of the components of each sample was obtained from the relative area of the peaks in the chromatograms.

\section{CYTOTOXIC ACTIVITY}

The cytotoxic activity was performed using the MTT method, which consists of a dosage based on the colorimetric conversion of the salt 3-(4,5-dimethyl-2-thiazole)-2,5 diphenyl-2-H bromide tetrazolium (MTT) which moved from a yellow color when insoluble [formazan crystals], moving to purple when precipitated due to the action of succinyl-dehydrogenase enzyme present only in metabolically active cells of mitochondria (Alley et al. 1988, Mosmann 1983). The human tumour cell lines used were NCI-H292 (lung mucoepidermoid carcinoma), MCF-7 (breast adenocarcinoma) and HEp-2 (epidermoid carcinoma of the larynx) obtained from the section of cell cultures of Bank Cell in Rio de Janeiro and maintained in accordance with the protocol established by the Cell Culture Laboratory, Department of Antibiotics of the Federal University of Pernambuco. Cells were maintained in Dulbecco's Modified Eagle Medium (DMEM) supplemented with 10\% fetal bovine serum, $1 \%$ antibiotic solution (penicillin and streptomycin) and $L$-glutamine, grown in culture plates with 96 wells at a concentration of $2 \times 10^{5}$ cells/well, incubated at $37^{\circ} \mathrm{C}$ in a humid atmosphere $\left(5 \% \mathrm{CO}_{2}\right)$ for 24 hours (Butler and Dawson 1992). Then the extracts Hx, DCM, CF and EtOAc leaves dissolved in dimethylsulfoxide (DMSO) (stock concentration $10 \mathrm{mg} / \mathrm{ml}$ ) were added to the wells in a single concentration (50 $\mu \mathrm{L} / \mathrm{ml})$ and doxorubicin $(5 \mathrm{mg} / \mathrm{ml})$ was used as a positive control. This procedure was performed in triplicate. After 72 hours of plate reincubation, 25 $\mu \mathrm{L}$ of MTT $(5 \mathrm{mg} / \mathrm{ml})$ was added to each well. The culture medium with MTT was aspirated, after 3 hours incubation, $100 \mu \mathrm{L}$ of DMSO was added to each well to dissolve the formazan crystals. The absorbance was measured in a spectrophotometer at a wavelength of $540 \mathrm{~nm}$. Cell growth inhibition percentage (CI\%) was determined considering the mean of negative control as $100 \%$ proliferation. An intensity scale was used to assess the cytotoxic potential of the extracts which were as follows: samples without activity, with little activity (cell growth inhibition ranging from 1 to $50 \%$ ), with moderate activity (cell growth inhibition ranging 
from 50 to $75 \%$ ) and high activity (growth inhibition ranging 75 to $100 \%$ ) (Fouche et al. 2008).

\section{RESULTS AND DISCUSSION}

Analysis by GC/MS of the Hx, DCM, CF and EtOAc extracts from leaves of $P$. microphyllum and P. mucronatum detected 51 constituents (Table I and Table II). These extracts contained a mixture of different compounds such as alkaloids, diterpenes, triterpenes, sterols, alcohols, aldehydes, fatty acids and hydrocarbons.

The constituents that showed relative larger areas (\%), from the extracts of P. microphyllum leaves, were Lup-20(29)-en-3-one (lupenone, $23.07 \%$ ) and (3ß)-Lup-20(29)-en-3-ol (lupeol, $16.95 \%$ ) in the Hx. In the DCM and CF extracts were lupeol (18.53\% and $16.19 \%)$, lupenone $(14.47 \%$ and $12.99 \%)$ and $(3 \beta)$-Estigmast5-en-3-ol ( $\beta$-sitosterol, 9.74\% and 9.45\%), and $N, N$-dimethyl-1H-indole-3-ethanamine (dimetiltriptamine 18.36\%) in CF. In the EtOAc extract, the compounds that had higher percentages were lupeol (20.86\%) and lupenone (18.69\%).

Regarding the extracts of the leaves of $P$. mucronatum, the constituents with the highest percentages were: lupeol $(8.33 \%)$, triacontane (8.71\%), pentacosane $(11.37 \%)$ in $\mathrm{Hx}$; in DCM, (Z)-11-octadecenoic acid (cis-vaccenic acid, $7.83 \%$ ), pentacosane $(8.35 \%)$; the CF, cis-vaccenic acid $(8: 35 \%)$, tetracosane $(7.85 \%)$ and EtOAc, hexacosane $(10.72 \%)$, tetratetracontane $(8.2 \%)$, lupenone (10.21\%) and lupeol (22.8\%).

Studies with ethanol extract of the aerial parts of $P$. greggii identified and isolated oleanoic acid (Dominguez et al. 1971). Rios et al. (2001) isolated a tetracyclic triterpene $(3,4$-seco-olean18-ene-3,28-dioic acid) from the aerial parts of $P$. reichenhachianum. López-Martínez et al. (2013) identified and isolated from the acetone extract of the leaves of P. brachystachyum morolic acid as the major component, and $\beta$-sitosterol, stigmasterol, triacontanol, squalene, $\alpha$ - and $\beta$-amyrin, lupeol, lupenone, betulin, oleanolic aldehyde, betulinic acid, betulonic acid, moronic acid, morolic acid, oleanolic acid.

Some of these compounds, such as $\beta$-sitosterol, squalene, lupeol and lupenone were detected in this study, indicating that various constituents are common among the different species of the genus Phoradendron. In addition, common constituents in different extracts of $P$. microphyllum and $P$. mucronatum were observed. These are: 7,11,15-trimethyl-3-methylene-1-hexadecene; (2E)-3,7,11,15-tetramethyl-2-hexadecen-1ol; $(2 R)-2,5,7,8$ tetramethyl-2-[(4R,8R)-4,8,12 trimethyltridecyl]-6-chromanol; 4,14-dimethyl9,19-cycloergost-24(28)-en-3-yl acetate and stigmast-4-en-3-one.

Consistent with the diversity of compounds detected, extracts from the leaves of P. microphyllum and $P$. mucronatum showed cytotoxic activity against strains analyzed (Table III). The percentages of inhibition of cell growth of extracts from $P$. microphyllum front line HEp-2 were $86.94 \%$ for DCM, $82.08 \%$ and $87.53 \%$ for EtOAc. The latter extract showed moderate activity (72.97\%) against NCI-H292.

The extract Hx of P. mucronatum inhibited cell growth of NCI-H292 and Hep-2 at $83.19 \%$ and $93.40 \%$ respectively. The DCM extracts showed inhibitory effect on HEp-2 (85.47\%) and MCF-7 (88.69\%). The CF showed inhibition of $77.75 \%$ for NCI-H292, and $91.46 \%$ for HEp-2 and EtOAc to extract inhibited Hep-2 line (72.17\%).

The cytotoxic activity of the Phoradendron genus has been reported. The ethanol and aqueous extracts of $P$. crassifolium (Polh) Eichier showed low toxicity in cultured HeLa cells (human cervix carcinoma) (Abad et al. 1999); the methanol extract of the leaves of $P$. vernicosum Greenm showed cytotoxic activity against cell line nasopharyngeal carcinoma (KB) (Caamal-Fuentes et al. 2011); the aqueous extract of the leaves of $P$. serotinum (Raf.) 
TABLE I

Constituents identified in extracts of leaves of $P$. mucronatum by GC/MS with the highest similarity indices or equal to $90 \%$.

\begin{tabular}{|c|c|c|c|c|c|c|c|}
\hline \multirow{2}{*}{$\begin{array}{c}\text { RT } \\
(\text { min) }\end{array}$} & \multirow[b]{2}{*}{ MW } & \multirow[b]{2}{*}{ Compound } & \multirow{2}{*}{$\begin{array}{c}\text { Molecular } \\
\text { formula }\end{array}$} & \multicolumn{4}{|c|}{ Relative Amount \% } \\
\hline & & & & $\begin{array}{l}\mathrm{Hx} \\
(1)\end{array}$ & $\begin{array}{l}\text { DCM } \\
(2)\end{array}$ & $\begin{array}{l}\mathrm{CF} \\
(3)\end{array}$ & $\begin{array}{c}\text { ACOEt } \\
\text { (4) }\end{array}$ \\
\hline $\begin{array}{c}30.145(4) \\
30.155(1) \\
31.030(2.3)\end{array}$ & 278 & $\begin{array}{l}\text { 7,11,15-Trimethyl-3- } \\
\text { methylene-1-hexadecene }\end{array}$ & $\mathrm{C}_{20} \mathrm{H}_{38}$ & 0.15 & 0.64 & 0.78 & 0.56 \\
\hline 31.585 & 278 & $\begin{array}{l}\text { 7,11,15-Trimethyl-3- } \\
\text { methylene-1-hexadecene }\end{array}$ & $\mathrm{C}_{20} \mathrm{H}_{38}$ & - & - & - & 0.56 \\
\hline $33.145(4)$ & & & & & & & \\
\hline $33.150(1)$ & 270 & Methyl palmitate & $\mathrm{C}_{17} \mathrm{H}_{34} \mathrm{O}_{2}$ & 0.42 & 0.21 & - & 0.25 \\
\hline $\begin{array}{l}34.000(2) \\
35.200(2) \\
35.215(3)\end{array}$ & 256 & Palmitic acid & $\mathrm{C}_{16} \mathrm{H}_{32} \mathrm{O}_{2}$ & - & 6.15 & 7.25 & - \\
\hline 38.365 & 294 & $\begin{array}{l}\text { Methyl }(9 E, 12 E)-9,12- \\
\text { octadecadienoate }\end{array}$ & $\mathrm{C}_{19} \mathrm{H}_{34} \mathrm{O}_{2}$ & 0.27 & - & - & - \\
\hline 38.590 & 296 & Methyl (9E)-9-octadecenoate & $\mathrm{C}_{19} \mathrm{H}_{36} \mathrm{O}_{2}$ & - & - & - & 0.36 \\
\hline 38.600 & 296 & $\begin{array}{l}\text { Methyl }(11 E)-11- \\
\text { octadecenoate }\end{array}$ & $\mathrm{C}_{19} \mathrm{H}_{36} \mathrm{O}_{2}$ & 0.55 & - & - & - \\
\hline $\begin{array}{l}38.885(4) \\
38.910(1)\end{array}$ & 296 & $\begin{array}{c}(2 E)-3,7,11,15 \text {-Tetramethyl-2- } \\
\text { hexadecen-1-ol }\end{array}$ & $\mathrm{C}_{20} \mathrm{H}_{40} \mathrm{O}$ & 0.35 & - & - & 0.36 \\
\hline 39.315 & 302 & $\begin{array}{c}5,8,11,14,17-\text { Icosapentaenoic } \\
\text { acid }\end{array}$ & $\mathrm{C}_{20} \mathrm{H}_{30} \mathrm{O}_{2}$ & 0.16 & - & - & - \\
\hline 40.395 & 280 & $\begin{array}{c}(9 Z, 12 Z)-9,12- \\
\text { octadecadienoic } \\
\text { acid }\end{array}$ & $\mathrm{C}_{18} \mathrm{H}_{32} \mathrm{O}_{2}$ & - & 2.08 & 2.12 & - \\
\hline 40.650 & 282 & (Z)-11-Octadecenoic acid & $\mathrm{C}_{18} \mathrm{H}_{34} \mathrm{O}_{2}$ & - & 7.83 & 8.35 & - \\
\hline 41.380 & 284 & Stearic acid & $\mathrm{C}_{18} \mathrm{H}_{36} \mathrm{O}_{2}$ & - & 0.89 & 0.94 & - \\
\hline $\begin{array}{c}48.195(1) \\
48.210(4) \\
48.940(2,3)\end{array}$ & 292 & $\begin{array}{l}\text { 12-Hydroxy-14-methoxy-3- } \\
\text { methyl-3,4,5,6,7,8,9,10- } \\
\text { octahydro-1H-2- } \\
\text { benzoxacyclododecin-1-one }\end{array}$ & $\mathrm{C}_{17} \mathrm{H}_{24} \mathrm{O}_{4}$ & 1.43 & 4.51 & 4.37 & 5.87 \\
\hline $\begin{array}{c}55.320(1,2,4) \\
56.175(3)\end{array}$ & 354 & Aspidospermine & $\mathrm{C}_{22} \mathrm{H}_{30} \mathrm{~N}_{2} \mathrm{O}_{2}$ & 0.52 & 1.22 & 1.20 & 1.30 \\
\hline $\begin{array}{l}57.455(1,4) \\
58.370(2,3)\end{array}$ & 410 & $\begin{array}{c}2,6,10,15,19,23-\text { Hexamethyl- } \\
2,6,10,14,18,22- \\
\text { tetracosahexene }\end{array}$ & $\mathrm{C}_{30} \mathrm{H}_{50}$ & 4.46 & 3.25 & 3.51 & 3.86 \\
\hline $\begin{array}{l}57.820(4) \\
58.680(3)\end{array}$ & 384 & Aspidospermidine & $\mathrm{C}_{23} \mathrm{H}_{32} \mathrm{~N}_{2} \mathrm{O}_{3}$ & - & - & 2.92 & 2.59 \\
\hline 59.630 & 366 & Hexacosane & $\mathrm{C}_{26} \mathrm{H}_{54}$ & - & - & - & 10.72 \\
\hline
\end{tabular}


TABLE I (continuation)

\begin{tabular}{|c|c|c|c|c|c|c|c|}
\hline \multirow{2}{*}{$\begin{array}{c}\text { RT } \\
(\min )\end{array}$} & \multirow[b]{2}{*}{ MW } & \multirow[b]{2}{*}{ Compound } & \multirow{2}{*}{$\begin{array}{c}\text { Molecular } \\
\text { formula }\end{array}$} & \multicolumn{4}{|c|}{ Relative Amount \% } \\
\hline & & & & $\begin{array}{l}\mathrm{Hx} \\
(1)\end{array}$ & $\begin{array}{l}\mathrm{DCM} \\
(2)\end{array}$ & $\begin{array}{l}\mathrm{CF} \\
(3)\end{array}$ & $\begin{array}{l}\text { ACOEt } \\
\text { (4) }\end{array}$ \\
\hline 59.640 & 352 & Pentacosane & $\mathrm{C}_{25} \mathrm{H}_{52}$ & 11.37 & - & - & - \\
\hline 60.530 & 338 & Tetracosane & $\mathrm{C}_{24} \mathrm{H}_{50}$ & - & - & 7.85 & - \\
\hline 60.535 & 352 & Pentacosane & $\mathrm{C}_{25} \mathrm{H}_{52}$ & - & 8.35 & - & - \\
\hline 61.830 & 394 & Octacosane & $\mathrm{C}_{28} \mathrm{H}_{58}$ & 0.92 & - & - & - \\
\hline $\begin{array}{l}63.995(4) \\
64.900(3)\end{array}$ & 619 & Tetratetracontane & $\mathrm{C}_{44} \mathrm{H}_{90}$ & - & - & 6.36 & 8.02 \\
\hline 64.005 & 422 & Triacontane & $\mathrm{C}_{30} \mathrm{H}_{62}$ & 8.71 & - & - & - \\
\hline $\begin{array}{l}64.205(4) \\
64.210(1) \\
65.085(2)\end{array}$ & 430 & $\begin{array}{c}((2 R)-2,5,7,8-\text { Tetramethyl-2- } \\
{[(4 R, 8 R)-4,8,12-} \\
\text { trimethyltridecyl]-6- } \\
\text { chromanol }\end{array}$ & $\mathrm{C}_{29} \mathrm{H}_{50} \mathrm{O}_{2}$ & 0.32 & 0.23 & - & 0.52 \\
\hline 64.905 & 366 & Hexacosane & $\mathrm{C}_{26} \mathrm{H}_{54}$ & - & 7.20 & - & - \\
\hline $\begin{array}{c}67.720(4) \\
67.735(1) \\
68.625(2.3)\end{array}$ & 414 & (3ß)-Stigmast-5-en-3-ol & $\mathrm{C}_{29} \mathrm{H}_{50} \mathrm{O}$ & 5.85 & 5.61 & 5.08 & 6.48 \\
\hline $\begin{array}{c}68.740(4) 69.655 \\
(2.3)\end{array}$ & 424 & Lup-20(29)-en-3-one & $\mathrm{C}_{30} \mathrm{H}_{48} \mathrm{O}$ & - & 7.46 & 7.19 & 10.21 \\
\hline $\begin{array}{c}69.120 \text { (3) } 69.125 \\
\text { (2) }\end{array}$ & 410 & 1-Octacosanol & $\mathrm{C}_{28} \mathrm{H}_{58} \mathrm{O}$ & - & 0.84 & 0.75 & - \\
\hline $\begin{array}{c}69.315(4) \\
69.320(1) \\
70.230(2.3)\end{array}$ & 426 & (3ß)-Lup-20(29)-en-3-ol & & 8.33 & 5.63 & 5.59 & 8.22 \\
\hline $\begin{array}{c}69.975(1.4) \\
70.885 \text { (3) } 70.895 \\
\text { (2) }\end{array}$ & 468 & $\begin{array}{c}\text { 4,14-Dimethyl-9,19- } \\
\text { cycloergost-24(28)-en-3-yl } \\
\text { acetate }\end{array}$ & $\mathrm{C}_{32} \mathrm{H}_{52} \mathrm{O}_{2}$ & 3.21 & 2.19 & 1.95 & 2.54 \\
\hline $\begin{array}{c}70.225(1) \\
70.230(4) \\
70.885(3) 71.120 \\
(2)\end{array}$ & 412 & Stigmast-4-en-3-ona & $\mathrm{C}_{29} \mathrm{H}_{48} \mathrm{O}$ & 5.62 & 3.97 & 3.92 & 5.64 \\
\hline 70.970 & 268 & Stearaldehyde & $\mathrm{C}_{18} \mathrm{H}_{36} \mathrm{O}$ & 0.53 & - & - & - \\
\hline
\end{tabular}

RT: retention time; MW: molecular weight; (1) Hx: hexane extract; (2) DCM: dichloromethane extract; (3) CF: chloroform extract and (4) EtOAc: ethyl acetate extract. 
TABLE II

Constituents identified in extracts of leaves of $P$. microphyllum by GC/MS with the highest similarity indices or equal to $90 \%$.

\begin{tabular}{|c|c|c|c|c|c|c|c|}
\hline \multirow{2}{*}{$\begin{array}{l}\mathrm{RT} \\
(\mathrm{min})\end{array}$} & \multirow[b]{2}{*}{ MW } & \multirow[b]{2}{*}{ Compound } & \multirow{2}{*}{$\begin{array}{l}\text { Molecular } \\
\text { formula }\end{array}$} & \multicolumn{4}{|c|}{ Relative Amount \% } \\
\hline & & & & $\begin{array}{l}\mathrm{Hx} \\
(1) \\
\end{array}$ & $\begin{array}{c}\text { DCM } \\
(2) \\
\end{array}$ & $\begin{array}{l}\mathrm{CF} \\
(3)\end{array}$ & $\begin{array}{c}\text { AcOEt } \\
(4)\end{array}$ \\
\hline $\begin{array}{l}28.535(2) \\
28.505(3) \\
28.660(4)\end{array}$ & 188 & 2-(1H-indol-3-yl)-N,Ndimethylethanamine & $\mathrm{C}_{12} \mathrm{H}_{16} \mathrm{~N}_{2}$ & - & 8.21 & 18.36 & 3.60 \\
\hline $\begin{array}{c}30.160(2,3) \\
30.165(4)\end{array}$ & 278 & $\begin{array}{l}\text { 7,11,15-Trimethyl-3-methylene-1- } \\
\text { hexadecene }\end{array}$ & $\mathrm{C}_{20} \mathrm{H}_{38}$ & - & 0.29 & 0.62 & 0.39 \\
\hline 37.025 & 328 & Hexadecanoic acid, trimethylsilyl ester & $\mathrm{C}_{19} \mathrm{H}_{40} \mathrm{O}_{2} \mathrm{Si}$ & - & - & - & 0.33 \\
\hline $\begin{array}{c}38.895(1,2,4) \\
38.890(3)\end{array}$ & 296 & $\begin{array}{l}(2 E)-3,7,11,15 \text {-Tetramethyl-2-hexadecen- } \\
1 \text {-ol }\end{array}$ & $\mathrm{C}_{20} \mathrm{H}_{40} \mathrm{O}$ & 7.20 & 6.61 & 6.33 & 7.26 \\
\hline 49.945 & 254 & Octadecane & $\mathrm{C}_{18} \mathrm{H}_{38}$ & 0.56 & - & - & - \\
\hline 52.495 & 268 & Nonadecane & $\mathrm{C}_{19} \mathrm{H}_{40}$ & 0.60 & - & - & - \\
\hline 54.955 & 394 & Octacosane & $\mathrm{C}_{28} \mathrm{H}_{58}$ & 1.49 & - & - & - \\
\hline 57.325 & 338 & Tetracosane & $\mathrm{C}_{24} \mathrm{H}_{50}$ & 1.59 & - & - & - \\
\hline $\begin{array}{c}57.460(1) \\
57.465(2,3,4)\end{array}$ & 410 & $\begin{array}{l}\text { 2,6,10,15,19,23- } \\
\text { Hexamethyl- } \\
\text { 2,6,10,14,18,22- } \\
\text { tetracosahexaene }\end{array}$ & $\mathrm{C}_{30} \mathrm{H}_{50}$ & 2.46 & 2.73 & 2.07 & 2.62 \\
\hline $\begin{array}{c}59.625(1) \\
59.630(2,3,4)\end{array}$ & 408 & Nonacosane & $\mathrm{C}_{29} \mathrm{H}_{60}$ & 5.32 & 3.02 & 3.00 & 2.85 \\
\hline 61.840 & 310 & Docosane & $\mathrm{C}_{22} \mathrm{H}_{46}$ & 1.06 & - & - & - \\
\hline 63.995 & 352 & Pentacosane & $\mathrm{C}_{25} \mathrm{H}_{52}$ & 0.91 & - & - & - \\
\hline $\begin{array}{c}64.220(1,2,3) \\
64.225(4)\end{array}$ & 430 & $\begin{array}{c}(2 R)-2,5,7,8- \\
\text { Tetramethyl-2-[(4R,8R)- } \\
\text { 4,8,12-trimethyltridecyl]- } \\
\text { 6-chromanol }\end{array}$ & $\mathrm{C}_{29} \mathrm{H}_{50} \mathrm{O}_{2}$ & 1.16 & 1.35 & 1.42 & 1.20 \\
\hline $\begin{array}{c}67.735(2,3) \\
67.730(4)\end{array}$ & 414 & (3ß)-Stigmast-5-en-3-ol & $\mathrm{C}_{29} \mathrm{H}_{50} \mathrm{O}$ & - & 9.74 & 9.45 & 8.37 \\
\hline $\begin{array}{c}68.730(1) \\
68.735(2) \\
68.740(3,4)\end{array}$ & 424 & Lup-20(29)-en-3-one & $\mathrm{C}_{30} \mathrm{H}_{48} \mathrm{O}$ & 23.07 & 14.47 & 12.99 & 18.69 \\
\hline $\begin{array}{l}69.310(1) \\
69.320(2) \\
69.315(3) \\
69.325(4)\end{array}$ & 426 & (3ß)-Lup-20(29)-en-3-ol & $\mathrm{C}_{30} \mathrm{H}_{50} \mathrm{O}$ & 16.95 & 18.53 & 16.19 & 20.86 \\
\hline
\end{tabular}


TABLE II (continuation)

\begin{tabular}{|c|c|c|c|c|c|c|c|}
\hline \multirow[b]{2}{*}{$\begin{array}{l}\mathrm{RT} \\
(\mathbf{m i n})\end{array}$} & \multirow[b]{2}{*}{ MW } & \multirow[b]{2}{*}{ Compound } & \multirow{2}{*}{$\begin{array}{l}\text { Molecular } \\
\text { formula }\end{array}$} & \multicolumn{4}{|c|}{ Relative Amount \% } \\
\hline & & & & $\begin{array}{l}\mathrm{Hx} \\
(1)\end{array}$ & $\begin{array}{c}\mathrm{DCM} \\
(2)\end{array}$ & $\begin{array}{l}\mathrm{CF} \\
(3)\end{array}$ & $\begin{array}{c}\mathrm{AcOEt} \\
(4)\end{array}$ \\
\hline $\begin{array}{l}69.985(2,3) \\
69.975(4)\end{array}$ & 468 & $\begin{array}{l}\text { 4,14-dimethyl-9,19-cycloergost-24(28)-en- } \\
\text { 3-yl acetate }\end{array}$ & $\mathrm{C}_{32} \mathrm{H}_{52} \mathrm{O}_{2}$ & - & 3.51 & 2.77 & 4.06 \\
\hline $\begin{array}{c}70.230(1) \\
70.235(2,3,4)\end{array}$ & 412 & Stigmast-4-en-3-one & $\mathrm{C}_{29} \mathrm{H}_{48} \mathrm{O}$ & 8.72 & 6.75 & 5.68 & 8.53 \\
\hline $\begin{array}{l}73.100(2,3) \\
73.105(4)\end{array}$ & 278 & $\begin{array}{l}\text { 7,11,15-Trimethyl-3-methylene-1- } \\
\text { hexadecene }\end{array}$ & $\mathrm{C}_{20} \mathrm{H}_{38}$ & - & 5.17 & 4.82 & 4.25 \\
\hline
\end{tabular}

RT: retention time; MW: molecular weight; (1) Hx: hexane extract; (2) DCM: dichloromethane extract; (3) CF: chloroform extract and (4) EtOAc: ethyl acetate extract.

TABLE III

Cell growth inhibition percentage (\%) of the extracts from leaves of Phoradendron microphyllum and Phoradendron mucronatum in three tumor cell lines at a concentration of $50 \mu \mathrm{g} / \mathrm{ml}$ by MTT method after 72 hours incubation.

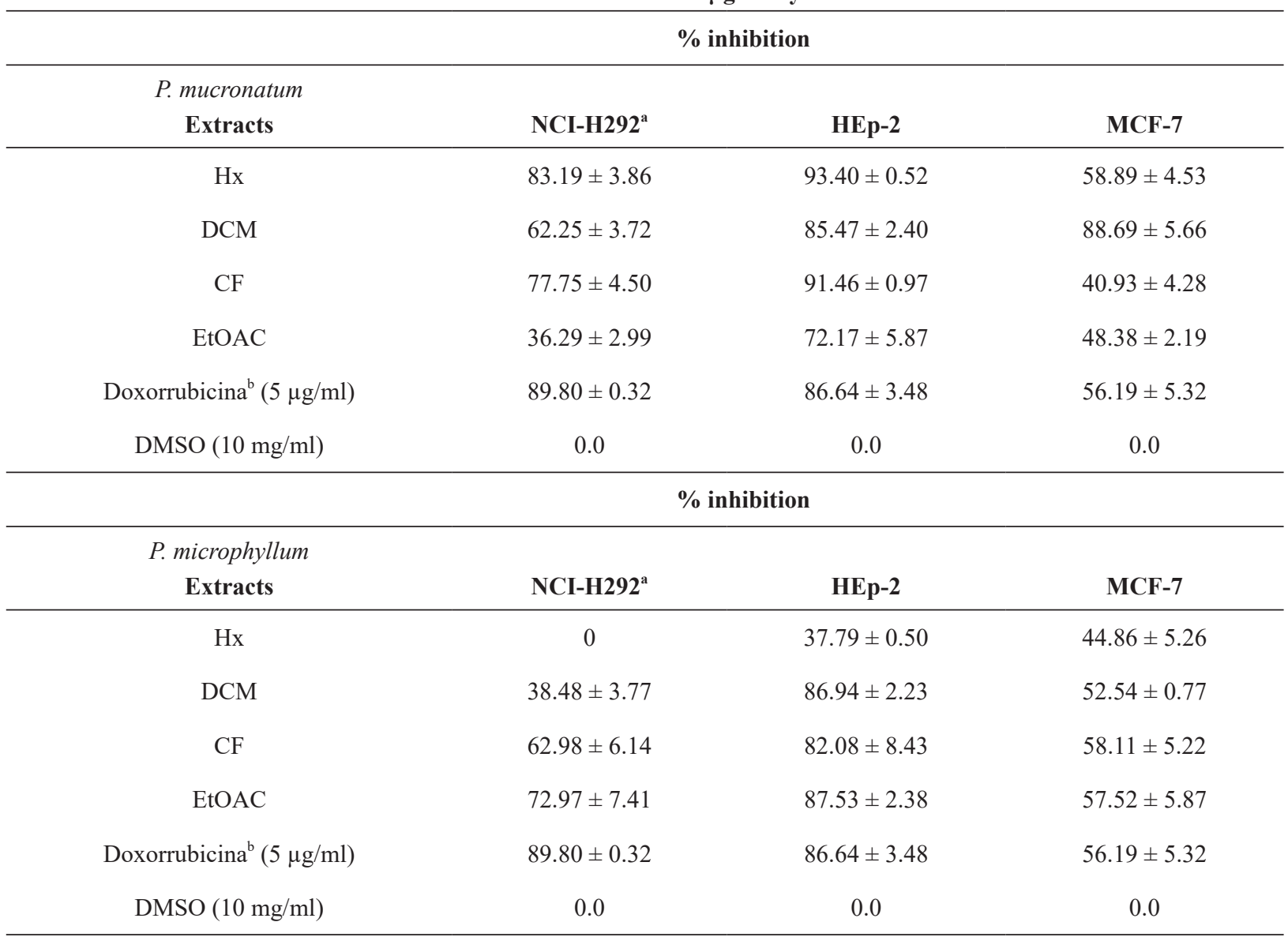

${ }^{\mathrm{a}}$ Human tumor cells lines: NCI-H292 (human pulmonary mucoepidermoid carcinoma); MCF-7 (human breast carcinoma) and HEp-2 (human larynx carcinoma); ${ }^{b}$ Positive control (Doxorrubicine - $5 \mu \mathrm{g} / \mathrm{ml}$ ); Hx: hexane extract; DCM: dichloromethane extract; CF: chloroform extract; EtOAc: ethyl acetate extract; DMSO: dimethylsulfoxide (Negative control - $10 \mathrm{mg} / \mathrm{ml}$ ). 
MC Johnst exerted toxic effects against cancer cells MCF-7 (adenocarcinoma human breast) (JacoboSalcedo et al. 2011); and the ethanol extract showed cytotoxic activity against TC-1 cells (derived from lung epithelium) (Alonso-Castro et al. 2012).

The percentage of inhibition of cell growth in different extracts may be related to the presence of certain groups of compounds such as alkaloids and triterpenes, known for their anticancer properties (Alonso-Castro et al. 2012).

The lupeol has been extensively studied, particularly in research involving the discovery of antitumor compounds (Saleem 2009). Some investigations have been carried out to evaluate the cytotoxic effects of lupeol on tumour cell lines such as Vero (African Green Monkey kidney), B16F10 (low wall melanoma) and HEp-2 (Badami et al. 2003).

The extracts (Hx, DCM, CF and EtOAc) of P. microphyllum and P. mucronatum showed cell percentages inhibition above $70 \%$ in the HEp-2 strain. It was observed that the lupeol was present in all extracts, but in higher percentages in the extracts of $P$. microphyllum.

Indole alkaloids were found in the two species under study. In the DCM, CF and EtOAc extracts of P. microphyllum have 2-(1H-indol-3-yl)- $N, N$ dimethylethanamine, also called Dimetiltriptamine (DMT). In Hx, DCM, CF and EtOAc extracts from P. mucronatum Aspidospermine was found and Aspidospermidine in the latter two extracts.

Alkaloids with amine groups and indole rings have been studied and various activities have been found, among them: antitumor, antiviral, antifungal and anti-inflammatory (Mcnulty et al. 2007, Griffin et al. 2007, Bao et al. 2004, Dassonneville et al. 2000, Xu et al. 2006).

Other research has been carried out with the purpose of showing that the alkaloids have a significant antiproliferative activity for solid tumours. These compounds have also selective cytotoxicity, a fact that stimulates a better investigation of their anticarcinogenic activity (Zhang et al. 2007, Wang et al. 2005).

Any of the extracts as well as the positive control (doxorubicin) presented an inhibition percentage above $75 \%$ (considered with high activity) against the MCF-7 line, except the DCM extract of the leaves of $P$. mucronatum. It is known that the breast cancer MCF-7 cells are resistant to chemotherapy, has low susceptibility to conventional drugs such as doxorubicin and cisplatin. This effect can be attributed to aberrant apoptotic pathway (Del Bufalo et al. 2002, Wesierska-Gadek et al. 2003).

\section{CONCLUSIONS}

Analysis by GC/MS allowed detection of 51 constituents in extracts of leaves of P. microphyllum and $P$. mucronatum. The constituents with higher percentages were lupenone (23.07\%), lupeol (18.53\%) and dimethyltryptamine (18.36\%) for P. microphyllum and pentacosane (11.37\%), hexacosane (10.72\%) and lupenone (10.21\%) for $P$. mucronatum. The different extracts of $P$. microphyllum showed cytotoxic activity against cell lines NCI-H292 and Hep-2, while the extracts of the species $P$. mucronatum showed inhibitory action towards the cell lines of NCI-H292, MCF7, HEp-2. The major cell growth inhibition percentages were observed in the species $P$. mucronatum possibly due to the wide variety of constituents detected.

\section{ACKNOWLEDGMENTS}

The authors would like to express their thanks for the grants and financial support received from Conselho Nacional de Desenvolvimento Científico e Tecnológico (CNPq), Coordenação de Aperfeiçoamento de Pessoal de Nível Superior (CAPES) and Fundação de Amparo a Ciência e Tecnologia do Estado de Pernambuco (FACEPE). 


\section{REFERENCES}

ABAD MJ, BERMEJO P, GONZALE E, IGLESIAS I, IRURZUN A AND CARRASCO L. 1999. Antiviral activity of Bolivian plant extracts. Gen Pharmacol 32: 499-503.

ALLEN JD, DORT SCV, BUITELAAR M, TELLINGEN OV AND SCHINKEL AH. 2003. Mouse breast cancer resistance protein (Bcrp1/Abcg2) mediates etoposide resistance and transport, but etoposide oral availability is limited primarily by p-glycoprotein. Cancer Res 63: 13391344.

ALLEY MC, SCUDIERO DA, MONKS A, HURSEY ML, CZERWINSKI MJ, FINE DL, ABBOTT BJ, MAYO JG, SHOEMAKER RH AND BOYD MR. 1988. Feasibility of drug screening with panels of human tumor cell lines using a microculture tetrazolium assay. Cancer Res 48: 589- 601.

ALONSO-CASTRO AJ, JUÁREZ-VÁZQUEZ M DEL C, DOMÍNGUEZ F, GONZÁLEZ-SÁNCHEZ I, ESTRADACASTILLÓN E, LÓPEZ-TOLEDO G, CHÁVEZ M, CERBÓN MA AND GARCÍA-CARRANCA A. 2012. The antitumoral effect of the American mistletoe Phoradendron serotinum (Raf.) M. C. Johnst. (Viscaceae) is associated with there lease of immunity-related cytokines. J Ethnopharmacol 142: 857-864.

ALONSO-CASTRO AJ, VILLARREAL ML, SALAZAROLIVO LA, GOMEZ-SANCHEZ M, DOMÍNGUEZ F AND GARCÍA-CARRANCAA. 2011. Mexican medicinal plants used for cancer treatment: Pharmacological, phytochemical and ethnobotanical studies. J Ethnopharmacol 133: 945-972.

BADAMIS, VIJAYANP,MATHEWN,CHANDRASHEKHAR R, GODAVARTHI A, DHANARAJ AS AND SURESH B. 2003. In vitro cytotoxic properties of Grewia tiliaefolia bark and lupeol. Indian J Pharmacol 35: 250-251.

BAO B, SUN Q, YAO X, HONG J, LEE CO, SIM CJ, IM KS AND JUNG JH. 2004. Citotoxic bisindole alkaloids from a marine sponge Spongosorites sp. J Nat Prod 68: 711-715.

BUTLER M AND DAWSON MM. 1992. Cell culture. Oxford: Bios Scientific, 268 p.

CAAMAL-FUENTES E, TORRES-TAPIA LW, SIMÁPOLANCO P, PERAZA-SÁNCHEZ SR AND MOO-PUC R. 2011. Screening of plants used in Mayan traditional medicine to treat cancer-like symptoms. J Ethnopharmacol 135: 719-724.

CARVALHAES SF, COSTA DL, MAZZEI JL, TADDEI LEM AND D'AVILA LA. 2002. Alternative extraction of alkaloid anticarcinogens from Brazilian "vinca rosea" using Ion Exchange chromatography. Rev Bras Farmacogn 12: $83-84$.

CHOI HJ, CHO BC, SHIN SJ, CHEON SH, JUNG JY, CHANG J, KIM SK, SOHN JH AND KIM JH. 2008. Combination of topotecan and etoposide as a salvage treatment for patients with recurrent small cell lung cancer following irinotecan and platinum first-line chemotherapy. Cancer Chemother Pharmacol 61: 309-313.

CRAGG GM, BOYD MR, CARDELLINA JH, NEWMAN DJ, SNADER KM AND MCCLOUD TG. 1994. Ethnobotany and drug discovery: the experience of the US National Cancer Institute. Ciba Found Symp 185: 178-190.

CRAGG GM, SCHEPARTZ SA, SUFFNESS M AND GREVER MR. 1993. The taxol supply crisis. New NCI policies for handling the large-scale production of novel natural product anticancer and anti-HIV agents. J Nat Prod 56: $1657-1668$.

CRONQUIST A. 1981. An integrated system of classification of flowering plants. New York, Columbia University Press, $1262 \mathrm{p}$.

DASSONNEVILLE L, LANSIAUX A, WATTELET A, WATTEZ N, MAHIEU C, MIERT SV, PIETER L AND BAILLY C. 2000. Cytotoxicity and cell cycle effects of the plant alkaloids cryptolepine and neocryptolepine: relation to drug-induced apoptosis. Eur J Pharmacol 409: 9-18.

DEL BUFALO D, BIROCCIO A, TRISCIUOGLIO D, BRUNO T, FLORIDI A, AQUINO A AND ZUPI G. 2002. Bcl-2 has differing effects on the sensitivity of breast cancer cells depending on the antineoplastic drug used. Eur J Cancer 38: 2455-2462.

DOMINGUEZ XA, ROJAS P AND SANZ VR. 1971. Loranthaceae: oleanolic acid from Phoradendron greggii. Phytochemistry 10: 1692.

FERREIRA CP, XAVIER HS AND PIMENTEL RMM. 2007. Estudo morfoanatomico foliar de Phoradendron mucronatum (D.C.) Krug. \& Urb. Rev Bras Bioci 5: 708710.

FOUCHE G, CRAGG GM, PILLAY P, KOLESNIKOVA N, MAHARAJ VJ AND SENABE J. 2008. In vitro anticancer screening of South African plants. J Ethnopharmacol 119: 455-461.

GORDALIZA M. 2007. Natural products as leads to anticancer drugs. Clin Transl Oncol 9: 767-776.

GRIFFIN C, SHARDA N, SOOD D, NAIR J, MCNULTY J AND PANDEY S. 2007. Selective cytotoxicity of Pancratistatin-relates natural Amaryllidaceae alkaloids: evaluation of the activity of two new compounds. Cancer Cell Int 7: 1-7.

GUPTA R, GABRIELSEN B AND FERGUSON SM. 2005. Nature's medicine: traditional knowledge and intellectual property management. Case studies from the National Institutes of Health (NIH), USA. Curr Drug Discov Technol 2: 203-219.

JACOBO-HERRERA NJ, JACOBO-HERRERA FE, ZENTELLA-DEHESA A, ANDRADE-CETTO A, HEINRICH M AND PÉREZ-PLASENCIA C. 2016. Medicinal plants used in Mexican traditional medicine for 
the treatment of colorectal cancer. J Ethnopharmacol 179: 391-402.

JACOBO-SALCEDO M DEL R ET AL. 2011. Antimicrobial and cytotoxic effects of mexican medicinal plants. Nat Prod Commun 6: 1925-1928.

JOHANSSON S, GULLBO J, LINDHOLM P, EK B, THUNBERG E, SAMUELSSON G, LARSSON R, BOHLIN L AND CLAESON P. 2003. Small, novel proteins from the mistletoe Phoradendron tomentosum exhibit highly selective cytotoxicity to human breast cancer cells. Cell Mol Life Sci 60: 165-175.

JOHNSON IS, ARMSTRONG JG, GORMAN M AND BURNETT JR JP. 1963. The vinca alkaloids: a new class of oncolytic agents. Cancer Res 23: 1390-1397.

LÓPEZ-MARTÍNEZ S, NAVARRETE-VÁZQUEZ G, ESTRADA-SOTO S, LEÓN-RIVERA I AND RIOS MY. 2013. Chemical constituents of the hemiparasitic plant Phoradendron brachystachyum DC Nutt (Viscaceae). Nat Prod Res 27: 130-136.

MCNULTY J, NAIR JJ, CODINA C, BASTIDA J, PANDEY S, GERASIMOFF J AND GRIFFIN C. 2007. Selective apoptosis-inducing activity of crinum-type Amaryllidaceae alkaloids. Phytochemistry 68: 1068-1074.

MOSMANN T. 1983. Rapid colorimetric assay for cellular growth and survival: application to proliferation and cytotoxicity assays. J Immunol Methods 65: 55-63.

RIOS MY, SALINAS D AND VILLARREAL ML. 2001. Cytotoxic activity of moronic acid and identification of the new triterpene 3,4-seco-Olean-18-ene-3,28-dioic Acid from Phoradendron reichenbachianum. Planta Med 67: 443-446.

SALEEM M. 2009. Lupeol, a novel-inflammatory and anticancer dietary triterpene. Cancer Lett 285: 109-115.

WANG HK. 1998. Plant-derived anticancer agents currently in clinical use or clinical trials. IDrugs 1: 92-102.

WANG Y, CHAN FL, CHEN S AND LEUNG LK. 2005. The plant polyphenol butein inhibits testosterone-induced proliferation in breast cancer cells expressing aromatase. Life Sci 77: 39-51.

WANI M, TAYLOR H, WALL M, COGGIN P AND MCPHAIL AT. 1971. Plant antitumor agentes: VI. The isolation and structure of taxol, a novel leukemic and antitumor agent from Taxus brefivolia. J Am Chem Soc 93: 2325-2327.

WESIERSKA-GADEK J, GUEORGUIEVA M AND HORKY M. 2003. Dual action of cyclin dependente kinase inhibitors: induction of cell cycle arrest and apoptosis. A comparison of the effects exerted by roscovitine and cisplatin. Pol J Pharmacol 55: 895-902.

XU YK, YANG SP, LIAO SG, ZHANG H, LIN LP AND YUE JM. 2006. Alkaloids from Gelsemium elegans. J Nat Prod 69: 1347-1350.

ZHANG J, YU D, LIU D AND LIU Z. 2007. Extraction and composition of three naturally occuring anticancer alkaloids in Camptotheca acuminata seed and leaf extracts. Phytomedicine 14: 50-56. 